Fighting Words 
This page intentionally left blank 


\section{Fighting Words}

Religion, Violence, and the

Interpretation of Sacred Texts

Edited by

John Renard

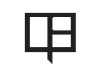

UNIVERSITY OF CALIFORNIA PRESS

Berkeley Los Angeles London 
University of California Press, one of the most distinguished university presses in the United States, enriches lives around the world by advancing scholarship in the humanities, social sciences, and natural sciences. Its activities are supported by the UC Press Foundation and by philanthropic contributions from individuals and institutions. For more information, visit www.ucpress.edu.

University of California Press

Berkeley and Los Angeles, California

University of California Press, Ltd.

London, England

(C) 2012 by The Regents of the University of California

Library of Congress Cataloging-in-Publication Data

Fighting words : religion, violence, and the interpretation of sacred texts / edited by John Renard.

p. $\mathrm{cm}$.

Includes bibliographical references and index.

ISBN 978-0-520-25831-O (cloth : alk. paper) — ISBN 978-0-520-27419-8 (pbk. : alk. paper) — ISBN 978-0-520-95408-3 (ebook)

1. Violence-Religious aspects. 2. Sacred books-History and criticism. 3. Religions-Relations. I. Renard, John, 1944BL65.V55F 642012

$201 \cdot .76332-\mathrm{dc} 23$ 2012029403

Manufactured in the United States of America

$\begin{array}{llllllllll}21 & 20 & 19 & 18 & 17 & 16 & 15 & 14 & 13 & 12\end{array}$

$\begin{array}{llllllllll}10 & 9 & 8 & 7 & 6 & 5 & 4 & 3 & 2 & 1\end{array}$

In keeping with a commitment to support environmentally responsible and sustainable printing practices, UC Press has printed this book on 50-pound Enterprise, a $30 \%$ post-consumer-waste, recycled, deinked fiber that is processed chlorine-free. It is acid-free and meets all ANsI/ NISO (z 39.48) requirements. 